\title{
PRINCIPAL EARTHQUAKES IN NEW ZEALAND IN 1994
}

\author{
W. D. Smith'
}

Earthquakes have occurred in New Zealand more frequently in the last five years than in the previous decade. This is not a cause for alarm, but a demonstration of the sporadic way in which they happen. It is clear that during the 1970s and early 1980s we experienced fewer large earthquakes than normal. Earthquakes in 1994 followed the established pattern of an active region from the Bay of Plenty to the northern South Island. We have again been fortunate that large earthquakes have not occurred close to our large cities.

One of the most significant earthquakes in New Zealand in recent years occurred on June 18, near Arthur's Pass [Paterson and Bourne-Webb, 1994; Pattle and Wood, 1994]. Its Richter magnitude was 6.6 , so it was very comparable to the damaging shock in Northridge, Los Angeles, on January 17 [Norton et al, 1994]. The Arthur's Pass earthquake was felt strongly in Christchurch, but damage there was very light because the epicentre was about $115 \mathrm{~km}$ from the city. There are some reports of minor damage in Christchurch and the surrounding towns. Localities closer to the epicentre sustained more damage but the Arthur's Pass area itself is sparsely populated. The earthquake was felt very strongly at Lake Coleridge, where an earthquake of magnitude 6.2 in June 1946 did considerable damage, especially to chimneys and brickwork.

Aftershocks began immediately, with one of magnitude 5.8 on 20 June and another of 5.6 on 21 June, then continued for months. On September 16, there was one of magnitude 4.9. Such an aftershock sequence is fully expected after an earthquake of this size. Seismological Observatory staff installed 20 portable seismographs, mostly to the south and west of Arthur's Pass, within the few days following the main shock. Within one week these recorded about 10,000 aftershocks, mostly very small but important for understanding the physical process going on in the Earth to produce such big earthquakes. These aftershocks are still awaiting full analysis, because of the amount of work involved. However the initial results show that the fault on which they occurred was oriented northwest-southeast, which is at right angles to the direction most seismologists and geologists expected. This implies a more complicated geological structure of the region than was presumed. Further work should throw light on this.

The Arthur's Pass region has had large earthquakes in the past. Notable was the magnitude 7 earthquake in March 1929, which has been overshadowed in popular memory by the larger shock which occurred in June of that year and caused extensive damage to Murchison, Nelson, Westport and Greymouth.

The Bay of Plenty is always an active area, particularly offshore, and 1994 was no exception. On December 16 an earthquake of magnitude 6.2 occurred $60 \mathrm{~km}$ north of White Island. Power was out for a short time in Opotiki, and some shops reported goods off shelves. It was felt throughout much

\footnotetext{
1 Institute of Geological \& Nuclear Sciences, Wellington
} (Fellow) of the Bay of Plenty. This area to the north of White Island has had a lot of earthquakes of this size in the past ten years, with huge sequences of smaller shocks, but they seem not to be related directly to the volcanic activity. The volcano-seismic earthquakes there are mostly quite small, though numerous, and very close to White Island.

Opotiki also suffered on March 9, when an earthquake of magnitude 5.9 occurred near there and again there are reports of goods off shelves. This one was also felt in Gisborne and Taumarunui. On April 23 an earthquake of magnitude 5.4 was reported felt in Auckland, but it was also out in the Bay of Plenty, in this case $100 \mathrm{~km}$ north of White Island. It was a long way from Auckland, so the effects there were very slight indeed. Most people would not have felt it at all. On June 5 an earthquake of magnitude 5 was felt in Tauranga and Matamata.

Fiordland is normally very active, but it was quieter in 1994 . On March 28 an earthquake of magnitude 5.1 was felt in Queenstown.

Deep earthquakes under the North Island are more frequent than shallow ones, and are often felt very widely. But they do little damage because of their depth. Some of the significant ones were: February 8, magnitude $5.4,40 \mathrm{~km}$ north of Stephen's Island in Marlborough Sounds, $118 \mathrm{~km}$ deep, felt Opunake to Christchurch; March 26, 5.5, just west of National Park, 205 $\mathrm{km}$ deep; February 23, 5.9, $191 \mathrm{~km}$ deep beneath South Taranaki, felt south to Christchurch; April 17, 5:4, $30 \mathrm{~km}$ north of Whakatane, $139 \mathrm{~km}$ deep, felt Gisborne; May 10, 5.0, $60 \mathrm{~km}$ deep, just south of Palmerston North, felt south to Wellington; September $10,6.0,20 \mathrm{~km}$ west of Whakatane at $190 \mathrm{~km}$ deep, felt south to Wellington.

In 1960 a pocket of very deep earthquakes was discovered beneath northern Taranaki, at a depth of almost $600 \mathrm{~km}$. Another occurred there this year: one of magnitude 5.1 on April 8. There are almost no earthquakes deeper than $300 \mathrm{~km}$, except in this isolated pocket. But their very great depth implies that they are not felt, and are of scientific interest only.

\section{REFERENCES}

Norton, J.A., A.B. King, D.K. Bull, H.E. Chapman, G.H. McVerry, T.J. Larkin, K.C. Spring. 1994. Northridge Earthquake Reconnaissance Report, Bulletin N.Z. National Society for Earthquake Engineering, 27(4):235-344.

Paterson, B.R. and P.J. Bourne-Webb. 1994. Reconnaissance report on highway damage from the 18 June 1994, Arthur's Pass earthquake, Bulletin N.Z. National Society for Earthquake Engineering, 27(3):222-226.

Pattle, A. and J.H. Wood. 1994. Ground shaking intensity and damage at Lake Coleridge Power station in the 18 June 1994 Avoca River earthquake, Bulletin N.Z. National Society for Earthquake Engineering, 27(3):227-230. 